\title{
Hanging Together, Together Hung? Career Implications of Interpersonal Ties Between CEOs and Top Managers
}

Stefan Hilger, Department of Strategy, Organization \& Leadership, EBS Business School, Germany, E-Mail: stefan.hilger@ebs.edu Ansgar Richter, Department of Strategy, Organization \& Leadership, EBS Business School, Germany, E-Mail: ansgar.richter@ebs.edu Utz Schäffer, Institute of Management Accounting and Control, WHU - Otto Beisheim School of Management, Germany, E-Mail: utz.schaeffer@whu.edu

\begin{abstract}
Is it good or bad for senior executives to have strong interpersonal ties to the CEO? We argue that a strong relationship with the CEO raises the likelihood that a top manager stays in office or makes an upward career move when the CEO leaves office voluntarily. At the same time, such interpersonal ties also reinforce the negative spillover effects of a dismissal of the CEO on the career prospects of the manager concerned. Our empirical analysis lends support to both arguments. We contribute to managerial succession research by underlining the ambivalence of interpersonal ties within top management teams.
\end{abstract}

JEL classification: D85, M51, G30

Keywords: corporate governance, interpersonal ties, top executive careers, top executive turnover, top management teams

Manuscript received February 6, 2012, accepted by Peter Walgenbach (Management) October 29, 2012.

\section{$1 \quad$ Introduction}

Close interpersonal ties to the Chief Executive Officer (CEO) are widely regarded as an important asset for other members of a firm's top management team (TMT). Senior executives benefit in a variety of ways from strong relationships with the CEO. For example, they may glean inside information, protection, and preferential treatment from such relationships (Adler 2001; Cao, Maruping, and Takeuchi 2006). In addition, close and long-standing relationships between the CEO and other senior managers may foster trust and support the formation of social capital (Adler and Kwon 2002; Coleman 1988; Leana and Van Buren 1999).

At the same time, having strong ties to the CEO may also be detrimental to senior managers, in particular when the CEO faces severe criticism and is dismissed. In these situations an executive, who has a close relationship with the CEO, may be seen as the CEO's "partner in crime", which could raise the likelihood that they, too, are dismissed, and hurt their chances of being promoted to the vacant CEO position. This "dark side" of strong interpersonal ties has largely been ignored in the literature to date. In this paper, we therefore investigate the career implications of interpersonal ties between a TMT member and the CEO of a firm from the perspective of the TMT member concerned. Our theory development suggests that under normal conditions, strong ties to the CEO are a source of stability, thus raising the likelihood that a manager will remain in office (Adler and Kwon 2002; Leana and Van Buren 1999). When the CEO leaves office for routine reasons (such as voluntary departure or retirement), strong interpersonal ties to the CEO enhance the possibilities for the manager to make an upward move. However, if the CEO faces disciplinary actions and is fired, a strong relationship with that CEO reinforces the negative spillover effects of the CEO's dismissal on the manager's own career pro- 
spects. Given the generally positive portrayal of interpersonal ties to the CEO in the literature so far (e.g., Cao, Maruping, and Takeuchi 2006; Collins and Clark 2003), we highlight a potential ambivalence in such ties, at least in critical situations such as the dismissal of the CEO.

In our empirical study, we investigate the career implications of interpersonal ties to the CEO from the perspective of a senior manager in a functional role that exists in virtually every large company, namely the Chief Financial Officer (CFO). CFOs are in a particularly challenging position, in that they should maintain a balance between independence from the CEO for the sake of greater neutrality and objectivity (Daily and Schwenk 1996), and closeness to the $\mathrm{CEO}$ as the primary strategic partner (Arthaud-Day, Certo, Dalton, and Dalton 2006; Collins, Masli, Reitenga, and Sanchez 2009; Tulimieri and Banai 2010; Zorn 2004).

Using a matched-pair design, we analyze data on 77 CFO-turnover events in large, stock-market-quoted companies in Germany between 1999 and 2006 to shed light on the ambivalence of strong interpersonal ties to the CEO. Using logistic regression techniques, we find support for our central expectations, namely that strong interpersonal ties to a CEO help to keep a top manager in office. At the same time, when the CEO leaves office, strong ties reinforce the effect of the CEO's departure on the likelihood that the TMT member will leave their position, too: If the CEO leaves for routine reasons, then a strong relationship with that CEO enhances the likelihood that the TMT member concerned will make an upward career move through internal promotion or a move to a better position elsewhere. However, if the CEO is dismissed, a strong relationship with that CEO increases the TMT member's risk of also being dismissed.

Our findings add to managerial succession research (Cao, Maruping, and Takeuchi 2006; Fee and Hadlock 2004; Mian 2001; Shen and Cannella 2002a) by highlighting the ambivalence of strong interpersonal ties.

\section{Theory and Hypotheses}

\subsection{The Importance of Relationships between TMT Members and the CEO}

According to social network perspectives, interpersonal ties among social actors encourage an attitude of goodwill, which facilitates information sharing, cooperation, and solidarity in the network concerned (Adler 2001; Granovetter 1973; Nahapiet and Ghoshal 1998). The strength of such ties is influenced through interaction frequency, duration, and emotional intensity or closeness of the relationship (Collins and Clark 2003). Strong interpersonal ties within TMTs are particularly important in that they foster trust and support the formation of social capital (Adler and Kwon 2002; Leana and Van Buren 1999; Lin 2001) which, in turn, may enhance the development of human capital (Coleman 1988). Therefore, strong interpersonal ties among TMT members may create benefits for both the firm and the individuals concerned.

With respect to the firm-level benefits of interpersonal ties in TMTs, the strategic value of senior executives to their organizations results not only from their individual knowledge, skills, and experiences, but also from the effectiveness of their cooperation (Cao, Maruping, and Takeuchi 2006; Collins and Clark 2003; Fee and Hadlock 2004). For example, top executives can generate additional value for the company through good teamwork (Hayes, Oeyer, and Schaefer 2006). Empirical evidence shows that a CEO's strategic contribution to the organization is determined by relationships both within and outside the firm e.g., with other members of the TMT (Geletkanycz and Hambrick 1997; Rodan and Galunic 2004; Smith, Collins, and Clark 2005). Furthermore, Hambrick (1995; 2007) regarded interpersonal ties as a precursor to what he called "behavioral integration" (a culture of shared objectives and strong collaboration) in TMTs, which helps avert team fragmentation. Behavioral integration in TMTs can enhance firm performance (Lubatkin, Simsek, Ling, and Veiga 2006).

There are also individual-level benefits to having a close working relationship with other TMT members, such as an enhanced willingness to help others or the sharing of privileged information (Burt 1997; Collins and Clark 2003). Senior executives below CEO level should benefit from strong interpersonal ties to the CEO. They may receive inside information, protection, and special treatment from this relationship, especially if they work for a distinguished CEO (Graffin, Wade, Porac, and McNamee 2008). A CEO may groom a manager with whom they have a close relationship as a potential successor or provide other opportunities for career advancement (Adler and Kwon 2002). From the 
Figure 1: Career Implications of Interpersonal Ties

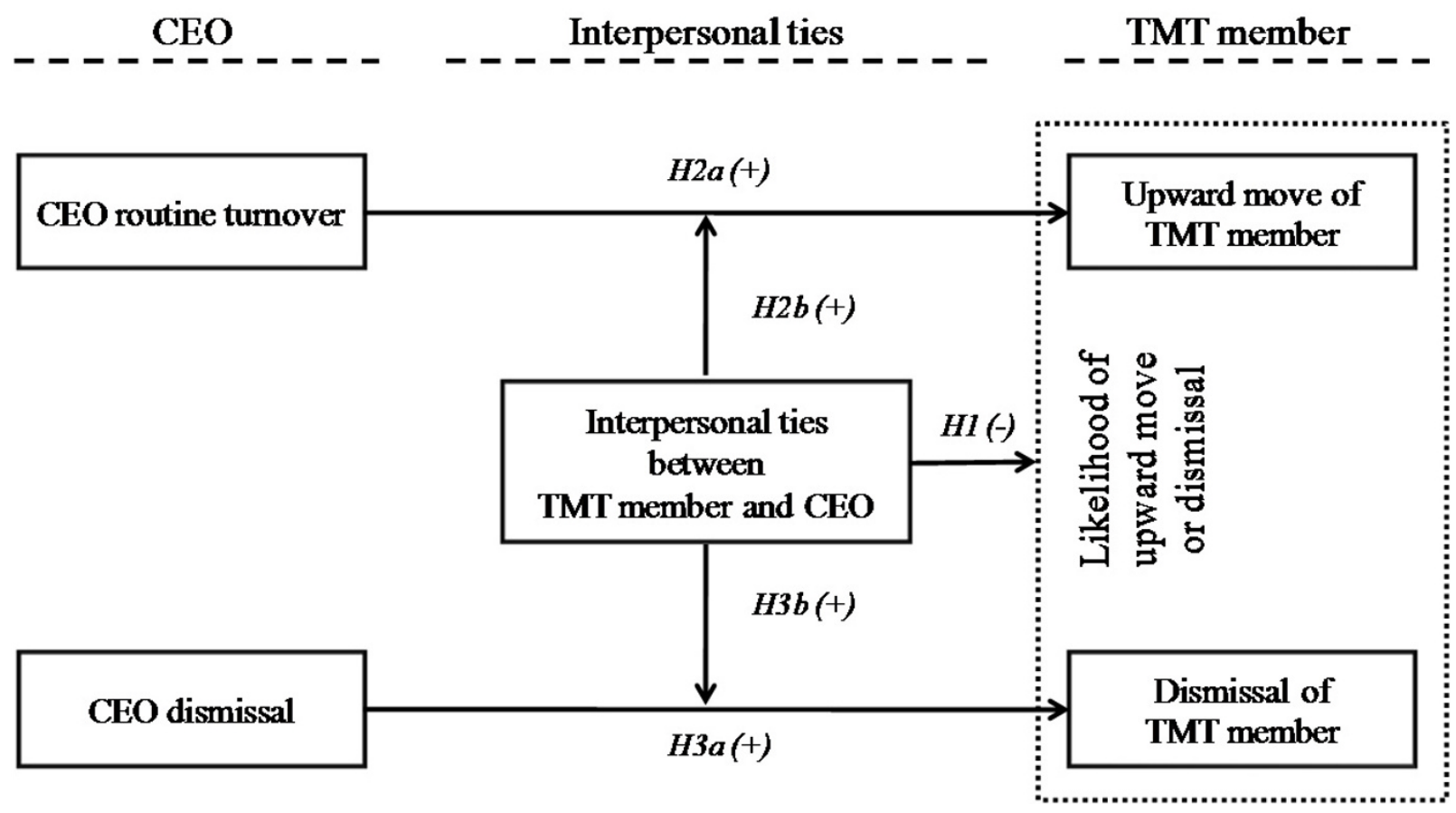

perspective of agency theory (Eisenhardt 1989; Sappington 1991), interpersonal ties may help prevent the emergence of problems such as opportunistic behavior, private benefit seeking, and others typically found in the relationship between the CEO and other TMT members (Cruz, Gomez-Mejia, and Becerra 2010; Hermalin and Weisbach 1998).

Likewise, strong interpersonal ties may also limit possible scapegoating behavior prompted by the $\mathrm{CEO}$, as sacrificing an affiliated executive is likely to be perceived as an acknowledgement of the duo's fault (Khanna and Poulsen 1995). Overall, strong interpersonal ties between the CEO and a TMT member indicate that an individual TMT member is part of the CEO's "inner circle", the coalition where the firm's most important strategic decisions are made (Hambrick and Mason 1984; Mooney and Amason 2011). From a corporate governance perspective, the importance of close working relationships among TMT members (and especially between the CEO and other members of a firm's TMT) is further highlighted by the fact that the corporate governance provisions in many countries - e.g., in the UK (see Financial Reporting Council 2010), and specifically in Germany (see below) - assign collective accountability to the senior management team. The notion of "collective accountability" implies a common responsibility, since both the CEO and other management board members are regarded as agents of superordinate principals (Fama 1980). Despite the arguments developed above, which favor strong interpersonal ties between the CEO and other TMT members, there may also be disadvantages to such close relationships. Classical expositions of principal-agent relationships (see Berle and Means 1932) focus primarily on the impersonal relationship between shareholders and managers (rather than on proximal relationships within TMTs). From this perspective, close interpersonal ties between the CEO and other TMT members may facilitate collusion and weaken the mechanisms for mutual control among agents (Daily and Schwenk 1996; Ocasio 1994). Interpersonal ties may also make managers less able or inclined to assess proposals for strategic actions, investments, and the like from different, independent perspectives (Rank and Tuschke 2010; Wiersema and Bantel 1992). Overall, principal-agent theory takes a skeptical perspective on the benefits of interpersonal ties among managers.

Furthermore, there may be situations in which strong ties to the CEO may be disadvantageous to individual TMT members. We expect that strong interpersonal ties between the CEO and other senior 
managers can result in a linkage of disciplinary action against both of them (Fee and Hadlock 2004). In the event of a dismissal or forced resignation of a CEO, executives with close relationships may be seen as "partners in crime". The stronger an alliance between the CEO and a top executive, the less likely the latter will be regarded either as a promising CEO successor or as a reliable and trustworthy strategic partner for the new CEO (Cao, Maruping, and Takeuchi 2006; Shen and Cannella 2002b). Furthermore, strong interpersonal ties to the former CEO may make it more difficult for a senior executive to establish good working relationships with a new CEO (Kesner and Dalton 1994). Overall, the arguments developed so far suggest that in the normal course of a firm's operations, strong interpersonal ties among the TMT members, in general, and between the CEO and other TMT members, in particular, should be beneficial to both the firm and the TMT members concerned. However, in more critical situations - e.g., when there are concerns regarding the effectiveness of the top team's governance, or if the CEO faces dismissal strong interpersonal ties to the CEO may also have detrimental effects. In our work, we focus specifically on the career implications of strong interpersonal ties to the CEO for an individual TMT member. Figure 1 depicts our theoretical model and hypotheses, developed below.

\subsection{Career Effects of Interpersonal Ties to the CEO for Individual TMT Members}

On the basis of the arguments so far, strong ties should be beneficial for individual TMT members in an established working relationship with the CEO, for several reasons: First, strong interpersonal ties with other colleagues, and in particular with senior ones, give individual managers access to inside information, allow work sharing, and ultimately raise individual (as well as collective) performance (Adler 2001; Granovetter 1973; Nahapiet and Ghoshal 1998). These factors, in turn, should result in greater recognition, higher compensation, and enhanced career prospects for the managers concerned (Adler and Kwon 2002). Second, CEOs are more likely to provide special protection and support to managers with whom they maintain close relationships, for example, in situations in which these managers face criticism or even the threat of dismissal (Adler 2001; Cao, Maruping, and Takeuchi 2006). Empirical research has shown that a CEO's social capital protects him/her from dismissal to some extent (Wrage, Tuschke and Bresser 2011); likewise, we should expect that a TMT member's social capital (which partially consists of strong interpersonal relationship with the CEO) also provides some protective power against dismissal. Third, there are significant emotional benefits of close relationships between managers, and these are particularly pronounced for relationships with seniors (Collins and Clark 2003). Having a "special relationship" with the CEO can also enhance one's status (Graffin, Wade, Porac, and McNamee 2008). Due to the correlation between individual performance and happiness (Ledford 1999), the performance-enhancing effects and emotional benefits of a close relationship with the CEO should further reinforce one another. For these reasons, we would expect that TMT members who have a close relationship with the CEO are less likely to leave their position voluntarily - in search of a position in another organization - or involuntarily (i.e., as a result of dismissal). Although the enhanced performance resulting from such a relationship may improve their job prospects on the external labor market, a move would signify the forfeiture of at least part of the basis for that strong performance. Moreover, a CEO who has a strong relationship with an individual member of their management team will generally invest more to keep that person on the team, and lend greater protection to them in situations when other parties (e.g., supervisory boards) are calling for their dismissal. Therefore, we expect strong interpersonal ties to the CEO to reduce the likelihood of a TMT member's turnover. In this context, the notion of "turnover" comprises all cases in which a TMT member leaves the focal organization, whether for voluntary (e.g., the acceptance of a position in a different organization) or involuntary (i.e., dismissal) reasons.

Hypothesis 1: Strong interpersonal ties to the CEO decrease the likelihood of turnover of a TMT member.

Thus far, the discussion of the value in interpersonal ties to the CEO relates primarily to a situation in which the CEO's position in office is stable. In contrast, when the CEO leaves the office, the vacant CEO position may either be filled by an external or an internal successor. The latter case also opens an opportunity for a TMT member to rise to the top of 
the organization. We assume that the succession type and context determine the requirements for the new CEO and, thus, influence the successor choice. Empirical studies have shown that CEO dismissal increases the likelihood that an outsider will be selected to succeed, whereas chances for insiders to succeed are higher in the case of routine CEO turnover, such as retirement or voluntary departure (Boeker and Goodstein 1993; Cannella and Lubatkin 1993; Datta and Guthrie 1994). Even if they are not promoted to the "top job", those seen as promising candidates for this position may ultimately benefit from the CEO's departure from the company. For example, a supervisory board that recognizes that a promising candidate has been "passed over" may give them an increased mandate in order to prevent the manager concerned from leaving their position voluntarily and reduce the potential negative consequences of fundamental changes in management (Barnett and Carroll 1995; Virany, Tushman, and Romanelli 1992).

Overall, we expect the turnover of a CEO for routine reasons to enhance the chances of other TMT members to make an upward career move. Such a career move may be internal (promotion to the CEO position, or to an enhanced role), or external e.g., when the TMT member decides to leave the company after being passed over in the promotion carousel. Even in the latter case, a rationally acting manager is unlikely to settle for a lesser position, but will leave the company when a position at least as good as the current one presents itself. Therefore, we hypothesize that:

Hypothesis 2a: A CEO routine turnover increases the likelihood that another TMT member makes an upward career move.

In addition, we expect strong interpersonal ties between the CEO and an individual TMT member to further reinforce the likelihood that the latter makes an internal or external upward move as the CEO leaves office. A manager with a close relationship to the departing CEO may either be considered a potential successor to the CEO (Hambrick, Geletkanycz, and Fredrickson 1993), or in case they are not offered the CEO role, may be promoted to another position internally. If the person concerned had any hopes for such a promotion - and strong interpersonal ties to the previous CEO may well lead an individual to consider themselves an "heir apparent" - and these hopes are disappointed, that per- son may well leave the organization voluntarily when the opportunity for at least an equivalent position elsewhere presents itself (Lambert, Larcker, and Weigelt 1993).

Furthermore, if the CEO makes an upward move (e.g., by becoming the CEO of a larger and more prestigious company), and they have a close relationship with a member of their previous team, they may try to take that manager with them to the new organization, which would likely imply an upward move for that manager, too. In contrast, a manager only loosely embedded into the CEO's social network may have less of an incentive to leave their position voluntarily.

Casual interpersonal ties to a CEO who leaves the company may well enable a manager to more easily develop a stronger relationship with the new CEO. In addition, it seems less likely that a manager with a departing CEO will follow them to a new organization, or be promoted directly to the CEO position. Therefore, we expect the strength of the interpersonal ties between a TMT member and a CEO who leaves office for routine reasons to moderate the effect of CEO turnover on the career prospects of the manager concerned.

Hypothesis 2b: Strong interpersonal ties between a TMT member and the departing CEO further increase the effect of CEO routine turnover on the likelihood of an upward move of the TMT member concerned, whereas weak interpersonal ties decrease this effect.

We also expect that the dismissal of a CEO increases the likelihood of other TMT members' dismissal. Dismissal can be regarded as the ultimate device to discipline top management; thus, it takes place primarily when corporate change is required (Shen and Cannella 2002b). Top executives determine new corporate strategies and strategic change is more likely to be initiated by managers recruited from outside the organization (Westphal and Fredrickson 2001). In this situation, principals (e.g., supervisory boards) may hold other TMT members coresponsible for the CEO's actions and perceived failures; including the failure to formulate and implement an effective strategy. Such cases of "punishment by association" should be particularly prevalent in corporate governance systems such as the German one, which stipulates the collective accountability of a management board. In line with this argument, Fee and Hadlock (2004) found that 
the dismissal of top managers below CEO level is mainly induced by the firing of the CEO, rather than by poor firm performance per se. Similarly, Hayes, Oyer, and Schaefer (2006) in their analysis of top management team composition changes in cases where a CEO leaves, showed that CEO turnover significantly increases the likelihood of TMT turnover. However, in light of research on the perceived negative consequences generally associated with a break in management continuity (Barnett and Carroll 1995, Virany, Tushman, and Romanelli 1992), we would expect supervisory boards to stagger their dismissals of multiple top managers, if at all possible. Overall, we hypothesize that:

Hypothesis 3a: A CEO dismissal increases the likelihood that another TMT member is dismissed.

Furthermore, the strength of the relationship between the management team and a CEO who faces dismissal influences the likelihood of a team member being dismissed, too. First, supervisory boards may view the members of the dismissed CEO's former social network as their "partners in crime" and extend the same criticism leveled against the CEO to these "allies" (Fee and Hadlock 2004). In contrast, managers with greater relational distance from the dismissed CEO are less likely to be associated with, and blamed for, their actions. Second, following a CEO dismissal, the successor in this position may want to distance themselves not only from the fired CEO, but also from the former CEO's social network (Cao, Maruping, and Takeuchi 2006). Therefore, the new CEO will offer less protection to members of that network, or even mead out disciplinary actions to the CEO's former associates. Alternatively, building constructive relationships with TMT members - a critical success factor for incoming CEOs is likely to be more difficult with managers closely related to the former CEO (Shen and Cannella 2002b). If the new CEO cannot build productive relationships with or fails to develop trust among existing TMT members, they might push for their replacement in order to make way for executives with whom better cooperation and a stronger relationship can be achieved (Kesner and Dalton 1994; Shen and Cannella 2002b). In sum, a strong relationship with a CEO who has been fired may, subsequently, increase the likelihood that a senior manager will be dismissed.
Hypothesis 3b: Strong interpersonal ties between a TMT member and the departing CEO further increase the effect of CEO dismissal on the likelihood that the TMT member concerned is dismissed, too, whereas weak interpersonal ties decrease this effect.

Overall, our theory suggests that interpersonal ties between a CEO and another TMT member affect the career prospects of the latter party. Under normal conditions - i.e., when there is no change in the CEO position - such ties will enhance the likelihood that the TMT member concerned stays in office. However, if the CEO leaves their position for routine reasons or as a result of disciplinary actions, a strong relationship with that CEO will further reinforce the effect that this change has on the likelihood that the manager concerned makes an upward career move, or is disciplined, too. In contrast, a weak relationship with the departing CEO will weaken these effects. In this sense, strong interpersonal ties to the CEO, while generally positive, may have an element of ambivalence for the executive concerned, in that they may raise the potential spillover effects of disciplinary actions leveled against the CEO.

\subsection{Whose Relationship with the CEO?}

Our argument developed above relates to the career implications of interpersonal ties from the perspective of an individual member of a firm's TMT. Testing this argument empirically benefits from focusing on senior managers in a particular functional role present in all firms under consideration, so as to hold this factor constant over the range of observations and exclude any variance associated with differences in career prospects between different managerial functions. We chose to investigate the career implications of CEO interpersonal ties for CFOs, for three interrelated reasons.

First, we sought to focus on a functional role that is present at management board level in the majority of firms in the population under study. In our research, we found that most publicly quoted companies in Germany that are contained in the leading stock market indices Deutscher Aktienindex (DAX) or Midcap-DAX (MDAX) had a CFO as a member of the management board, while there was substantial variation between firms in all other functional positions. Existing research confirms that the CFO is 
also the predominant executive - alongside the CEO - in the Anglo-Saxon system of corporate governance (Nath and Mahajan 2008).

Second, in order to play their role effectively, the CFO needs to have a relatively strong relationship with the CEO. Considerable literature attests to the significant increase, in recent years, in the CFO's importance as "co-pilots of" or "key strategic partners to" the CEO (Arthaud-Day, Certo, Dalton, and Dalton 2006; Collins, Masli, Reitenga, and Sanchez 2009; Menon and Williams 2008; Mian 2001; Zorn 2004). Both the accounting literature (Baxter and Chua 2008; Geiger, North, and O'Connell 2005) and the management literature (Logue 2010; Menz 2012; Nicholson and Cannon 2000; Tulimieri and Banai 2010) attribute a central strategic role to CFOs, beyond their traditional, more narrowly defined functional tasks. At the same time, however, the CFO needs to balance this need for proximity with the necessary independence and neutrality. Several corporate governance jurisdictions have put greater weight on the accountability of the $\mathrm{CFO}$ role in recent years. For example, the Sarbanes-Oxley Act, introduced in the US in 2002, attributed greater responsibility to the CFO (U.S. House of Representatives 2002), while substantially strengthening the position (Geiger and North 2006; Rehbein 2010).

Third, in line with their generally increased role, CFOs are becoming increasingly likely to advance into CEO positions, rather than to stay within their functional role until the end of their careers (Ocasio and Kim 1999). For these reasons, we view the CFO to be a particularly suitable role in our endeavor to study the career implications of a TMT member's interpersonal ties to the CEO.

\subsection{The Importance of the German Corporate Governance Context}

Our empirical work focuses on the German corporate governance system, which is characterized by a dual board structure with the supervisory board (Aufsichtsrat) and the management board (Vorstand) (see, for example, Baums and Scott 2005). This context is particularly well-suited for a study of the ambivalent career effects of strong interpersonal ties between the CEO and other TMT members for at least two reasons.

First, German corporate law mandates collective decision-making in the management board (\$77 Section 1 of the German Stock Corporation Act [Ak- tiengesetz; AktG]). Thus, close cooperation in a well-integrated TMT is particularly important in this context for both economic and legal reasons. Second, due to the relative independence of the supervisory board and the explicit requirement that the supervisory board appoints, monitors, and given sufficient cause - dismisses the CEO as well as other non-CEO management board members, (see \$84 Section 3 AktG), Germany has the highest dismissal rate of underperforming CEOs and other top managers worldwide (see Lucier, Schuyt and Tse 2005). Thus, to the extent that they do exist, one should be able to track career effects of CEO turnover, and in particular of CEO dismissal, on other top executives in using a sample of German firms.

\section{Data and Methods}

\subsection{Sample and Data Collection}

The key sources for our empirical data were the databases LexisNexis (for information on executive turnover), Datastream and Worldscope from Thomson Financial (for firm performance metrics), and Hoppenstedt Aktienfuihrer (a database that provides detailed information on German corporations), as well as annual reports from the companies concerned. Our study examines all companies that featured their primary listing in the DAX or MDAX for at least a full year between January 1998 and December 2006. For these companies, the analysis included all the years ( $n=916$ company years) during which the company was listed on a German stock exchange.

This approach keeps the company sample relatively constant across the period of analysis. Changes in the composition of indices and the restructuring of the MDAX in 2003 (the number of companies it covers was reduced from 70 to 50) consequently have less impact on the analysis. We included companies from the first full year in which they were listed until the last full year within the period of analysis before a merger or liquidation.

\subsection{Variables}

\subsubsection{Upward move and dismissal of a TMT member}

We identified all members of the management boards at the sample companies. As discussed above, we analyze the career implications of 
Table 1: Classification of CFO Turnover

Type of CFO turnover

\begin{tabular}{|c|c|c|c|}
\hline & & & \\
\hline \multirow{5}{*}{ Upward move } & Total & 47 & $29.2 \%$ \\
\hline & Promotion to CEO within the organization & 9 & $5.6 \%$ \\
\hline & $\begin{array}{l}\text { Increased remit/more responsible role on the management } \\
\text { board }^{\text {a }}\end{array}$ & 14 & $8.7 \%$ \\
\hline & Transition to the supervisory board ${ }^{\mathrm{b}}$ & 4 & $2.5 \%$ \\
\hline & Departure to other organization for career reasons & 20 & $12.4 \%$ \\
\hline \multirow{4}{*}{ Dismissal } & Total & 30 & $18.6 \%$ \\
\hline & Differences of opinion, e.g., with CEO/supervisory board & 11 & $6.8 \%$ \\
\hline & Explicit failure & 10 & $6.2 \%$ \\
\hline & Early contract termination/unexpected announcement & 9 & $5.6 \%$ \\
\hline \multirow{9}{*}{$\begin{array}{l}\text { Other } \\
\text { turnover } \\
\text { cases }\end{array}$} & Total & 84 & $52.2 \%$ \\
\hline & Turnover due to merger or acquisition & 6 & $3.7 \%$ \\
\hline & Interim changes & 2 & $1.2 \%$ \\
\hline & Prior vacancy in $\mathrm{CFO}$ position & 6 & $3.7 \%$ \\
\hline & No relevant information on turnover available & 6 & $3.7 \%$ \\
\hline & Separation of Finance division from CEO command & 20 & $12.4 \%$ \\
\hline & Departure for personal reasons and motivations & 15 & $9.3 \%$ \\
\hline & Health issues & 2 & $1.2 \%$ \\
\hline & Planned/ordinary retirement & 27 & $16.8 \%$ \\
\hline \multicolumn{2}{|c|}{ All identified changes in the leadership of the Finance division } & 161 & $100.0 \%$ \\
\hline
\end{tabular}

a This category includes assuming more responsible roles on the management board, e.g., adoption of COO role in addition to CFO role.

${ }^{b}$ The results of our analysis are not materially affected by whether these four cases are counted as "upward moves" or omitted from the analysis.

interpersonal ties between the CEO and a particular member of a firm's TMT in a specific functional role, namely the CFO. Therefore, we first identified the one executive in each company whose function was explicitly listed as CFO in the Hoppenstedt Aktienfuihrer or in a company's annual financial statement. In the remaining cases, for which this procedure did not yield conclusive information on the functional responsibilities of management board members, clarification was based on information in LexisNexis, which includes newspaper articles and ad-hoc reports.

We determined CFO turnover for each company by comparing the names of the $\mathrm{CFO}$ at the end of successive years. In addition, we used newspaper articles in LexisNexis to check whether additional turnover occurred over the course of the year. In total, we found 161 cases of CFO turnover in the period of analysis, which extended from 1999 to 2006 . We conducted a content analysis of newspaper articles published one to two years prior to and following each turnover event in order to determine the reasons for the change. This procedure yielded about 3,000 articles for the 161 turnover cases. Two raters, independently of one another, used the newspaper articles to classify these turnover cases as belonging to one of the three categories upward move, dismissal, and other turnover cases.

The raters classified a turnover case as an upward move if the $\mathrm{CFO}$ was promoted to the $\mathrm{CEO}$ position within the same organization or to another position clearly superior to the their previous position (e.g., through the extension of their role), or if the executive concerned left the firm for career reasons to assume a more responsible role in another organization. As Table 1 illustrates, our sample contains 9 
cases where the $\mathrm{CFO}$ was promoted to the position of $\mathrm{CEO}, 20$ cases where the CFO left their position for an external career, and 14 cases where the CFO assumed more responsible roles on the management board e.g., by assuming a role as Chief Operating Officer (COO) in addition to their role as CFO. There were also four cases where a CFO relinquished this role to assume a position on the supervisory board of the company concerned, a practice that was still possible in the years to which our data refer (it is now severely constrained).

It is debatable whether moving from a CFO role to a supervisory board role constitutes an "upward career move": On the one hand, supervisory board positions carry significant status gains, and are often considered a sign of "true seniority". Unsurprisingly, the "promotion" of TMT members to the supervisory board was a common practice in German DAX and MDAX companies before the amendment of the German Stock Corporate Act in 2009 (Bresser and Valle Thiele 2008). On the other hand, supervisory board positions tend to carry a lower remuneration than management board roles. In order to check the robustness of our results, we tested our hypotheses both with and without these four cases of CFO "upward moves" to the supervisory board, and found that our results were not materially affected by this choice.

In line with the approach by Bresser, Valle Thiele, Biedermann, and Lüdeke (2005), turnover cases were classified as dismissals if there were clear indications of differences of opinion between the manager and the supervisory board or the CEO, explicit failings were named as reasons for the dismissal, or the contract was terminated unexpectedly and prematurely without reasonable explanation. Other turnover cases included those due to mergers and acquisitions, planned/ordinary retirement, or departures for personal reasons and motivations.

In $95 \%$ of cases, the two independent classifications matched, corresponding to a Cohen (1960) Kappa of 0.87 and a Perreault and Leigh (1989) coefficient of 0.96 . Both coefficients are comparable with the values reported in similar studies on top management turnover, and indicate high reliability of the turnover classification. In total, 47 cases were classified as upward moves and 30 as dismissals; these 77 cases are the main focus of our regression analysis below. Table 1 gives an overview of the results of the classification.
We employed a matched-pair design as follows. For each company that saw an upward move or a dismissal in the CFO position as described above we assigned each year of the sample period to a reference year of a comparable control company within the same industry that did not have such an event. If several matches were available for one company year in which an upward move or a dismissal took place, we selected the one with the least difference in terms of total assets. The analyses presented in Tables 3-5 below relate to the comparison of the 77 upward move/dismissal company-year observations and the 77 corresponding reference years for control companies in the year before the turnover $\left(t_{-1}\right)$.

\subsubsection{CEO routine turnover and dismissal}

We followed a similar identification and classification procedure as described above for CEO turnover. In total, we found 116 cases of CEO turnover in our period of analysis, from which 67 were classified as routine turnover and 49 as dismissal. We then investigated all 77 upward move and dismissal cases of CFOs and the 77 matching control cases for preceding CEO turnover. To determine preceding CEO turnover in the control cases, we used the upward move/dismissal date of the corresponding case as the point of reference for the period of analysis. Since we expect the supervisory board to carry out the dismissals with a certain time-lag, we chose the time frame of one year prior to the upward move or dismissal of the $\mathrm{CFO}$ and created the dummy variables preceding $C E O$ routine turnover and preceding $C E O$ dismissal.

Out of the 116 cases of CEO turnover, we identified 41 preceding CEO turnover cases. 26 cases of these were classified as $C E O$ routine turnover. We gave the variable preceding $C E O$ routine turnover the value 1 in those cases, and o otherwise. The remaining 15 cases were classified as $C E O$ dismissals. Again, we assigned the variable preceding $C E O$ dismissal the value 1 in these cases and a value of 0 otherwise.

\subsubsection{Interpersonal ties}

As discussed above, interpersonal ties between the CEO and other TMT members are a multidimensional construct. A long duration, frequent interactions, and emotional closeness contribute to strong interpersonal ties between actors (Collins and Clark 
2003; Granovetter 1973). In order to account for this multidimensionality appropriately, we calculated five different proxies of interpersonal ties, namely mutual tenure in office, mutual firm tenure, age difference, simultaneous entrance in office, and common field of study.

Long-term cooperation indicates a higher level of embeddedness of individual managers in a CEO's social network. We, therefore, expect that a CEO and a manager who have worked together within the same firm and within the same management board for a longer period of time are likely to have stronger interpersonal ties than a CEO and a manager who have cooperated only for a shorter period of time (Cao, Maruping, and Takeuchi 2006; Collins and Clark 2003; Hayes, Oyer, and Schaefer 2006). Long-tenured top management teams are also found to be more committed to the firm, and the mindset of the individual team members will be more similar in long-tenured than short-tenured teams (Boeker 1997; Carpenter, Geletkanycz, and Sanders 2004; Finkelstein and Hambrick 1990; Keck 1997). Hence, we measure the duration of the relationship by the two variables mutual tenure in office and mutual firm tenure.

We do not have appropriate data available to measure the frequency of interaction between CEOs and other TMT members, but we created three variables measuring the emotional intensity or closeness of this relationship. As shown in previous studies, CEOs tend to build interpersonal ties to TMT members who are similar to themselves in terms of their age and experience (Finkelstein, Hambrick, and Cannella 2009; Mooney and Amason 2011). Our first variable, age difference, measures the absolute difference in age between the CFO, as the TMT member in focus, and the CEO. The greater this absolute age difference, the weaker the expected CEO-CFO interpersonal ties and vice versa. We further created the dummy variable simultaneous entrance in office which takes the value of 1 if both the $\mathrm{CFO}$ and the CEO started their job on the management board at the same time (within one month) and o otherwise. As a last measure for the emotional closeness of the relationship, we created the dummy variable common field of study which takes the value of 1 if both the CFO and the CEO had a higher education in a similar field (e.g., economics, engineering, law) and o otherwise. Commonality in educational background has been found to be a significant predictor of behavioral integration in TMTs (Simsek, Veiga, Lubatkin, and Dino 2005). Finally, the measures of the five proxy variables of interpersonal ties were factor analyzed. They loaded on one factor (Eigenvalue $=1.47$ ), which accounts for 29 percent of the variance. Thus, we created a composite measure of $\mathrm{CEO}-\mathrm{CFO}$ interpersonal ties based on standardized factor scores, which has a mean of 0 and a standard deviation of 1 . We also checked the robustness of our results by including in our regressions a measure of interpersonal ties that relied solely on the two variables mutual tenure in office and mutual firm tenure. The reason for this approach was that it can be argued that the other three variables (age difference, simultaneous entrance in office, and common field of study) are measures of homophily - "perhaps the most robust empirical regularity describing social relations" (Kleinbaum, Stuart and Tushman 2011: p. 1) which may be an antecedent of the formation of a relationship, but not necessarily a measure of relationship quality between two TMT members. However, our two-dimensional measure involving $\mathrm{mu}$ tual tenure in office and mutual firm tenure only yielded largely similar results to those of the fivedimensional measure. As the five-dimensional measure is richer than the two-dimensional one, we decided to display the results of the former.

\subsubsection{Control variables}

Principal-agent theory (Jensen and Meckling 1976) interprets a negative association between firm performance and top executive dismissal as the result of a disciplinary mechanism (Denis and Denis 1995). Empirical evidence broadly confirms this association regarding the position of CEO (Bresser, Valle Thiele, Biederman, and Lüdeke 2005; Coughlan and Schmidt 1985; Huson, Parrino, and Starks 2001; Kaplan 1994; Weisbach 1988), of the CFO (Mian 2001), and other TMT members (Fee and Hadlock 2004). Therefore, we control for firm performance in our analyses.

Firm performance may be seen as a multidimensional phenomenon (Shen and Cannella 2002a) for which multiple measures exist. In line with recent studies on management turnover (Bresser, Valle Thiele, Biederman, and Lüdeke 2005; Huson, Malatesta, and Parrino 2004), we use Operating Return on Assets $(O R o A)$ to control for firm performance in our study. ORoA appears especially relevant for the 
topic of this study as this measure reflects operational firm performance and is also fairly independent of short-term accounting policy manipulation (Dowdell and Krishnan 2004; Geiger and North 2006; Geiger, North, and O'Connell 2005). We adjusted the measure for industry and annual effects by calculating the difference between the respective performance metrics of the company and the industry median in the year concerned for those metrics based on the Industry Classification Benchmark (ICB) provided by Thomson Financial. We further control for contextual factors (Friedman and Singh 1989) such as firm size (calculated as the logarithm of total assets), firm age, CFO tenure in office, $C F O$ age, and the shareholder structure, measured as the share of institutional investors. Following Denis, Denis, and Sarin (1997) and Denis and Serrano (1996), we also took into account the potential interaction effects between the share of institutional investors and firm performance. Furthermore, we experimented with $\mathrm{CEO}$ and $\mathrm{CFO}$ gender as potential control variables. However, due to the fact that TMTs in Germany are still fairly male-dominated, there were very few cases of female executives in our sample, and despite including gender-related dummy variables in our analyses, the results were not affected in any material way.

\subsection{Statistical Analysis}

We tested our hypotheses using hierarchical logistic regressions. Kolmogorov-Smirnov tests showed that the forced and routine turnover incidences were normally distributed. The hierarchical logistic regression analyses allowed us to enter the explanatory variables in a stepwise fashion, thus determining their individual and joint contributions. We used three hierarchical logistic regression models to predict the overall likelihood of $C F O$ upward move or dismissal taken together, and four hierarchical logistic regression models to predict $C F O$ upward moves and $\mathrm{CFO}$ dismissals, respectively. In the first model, we entered our control variables into the regression equations. Afterwards, we entered our explanatory variables according to our hypotheses, and finally the interaction terms to analyze the role of interpersonal ties.

When testing moderator interactions in a logistic regression, it is suboptimal to rely on the strength, significance, and direction of the interaction term (Hoetker 2007). The interaction coefficient depends on the value of the moderator variable and the values and coefficients of all other variables in the model. It is not a constant, which makes the analysis and interpretation of moderating hypotheses more complex (Wiersema and Bowen 2009). Therefore, we used a methodology recommended by Ai and Norton (2003) and used by Lel and Miller (2008) in a similar context to compute the true interaction effect and test its statistical significance, which is based on the estimated cross-partial derivative (Norton, Wang, and Ai 2004).

\section{$4 \quad$ Results}

Table 2 reports the means, standard deviations, and correlations for the dependent, independent, and control variables in our study. In any given year of our period of analysis (1999-2006; $n=916$ company years), the likelihood of upward move for CFOs is higher (0.05) than the likelihood of dismissal (0.03). CFOs in our sample are on average 51.08 years old and stay in office for 5.14 years. The correlations show that firm performance and CFO tenure in office seem to negatively influence the likelihood of CFO dismissal (-0.31/-0.36). Moreover, we find high positive correlations between $\mathrm{CEO}-\mathrm{CFO}$ interpersonal ties and CFO tenure in office (0.66) as well as CFO age (0.46), which is not surprising, since old and long-tenured CFOs are expected to be deeply embedded into a firm's social network.

The correlations reported in Table 2 are of moderate magnitude. In order to avert any multicollinearity problems, we ran our regression models as ordinary least squares (OLS) regressions to examine the variance inflation factors (VIFs). The VIFs ranged from 1.00 to 3.08 in the different models, which is well below even a stringent threshold of 4 (O'Brien 2007). Hence, multicollinearity should not be a problem in our research. We tested our hypotheses using hierarchical logistic regression models (Tables $3-5$ ). When interpreting the fit statistics, note that McFadden's Pseudo $R^{2}$ in logistic regressions is no direct equivalent to the $R^{2}$ in OLS regressions. McFadden's Pseudo $R^{2}$ provides indications regarding the power of the independent variables to successfully discriminate between $\mathrm{CFO}$ upward move/dismissal cases and the matching control cases. When comparing different models on our data, the McFadden's Pseudo $R^{2}$, which takes a value between 0 and 1 , will be higher for the models with the greater likelihood (Hoetker 2007). 


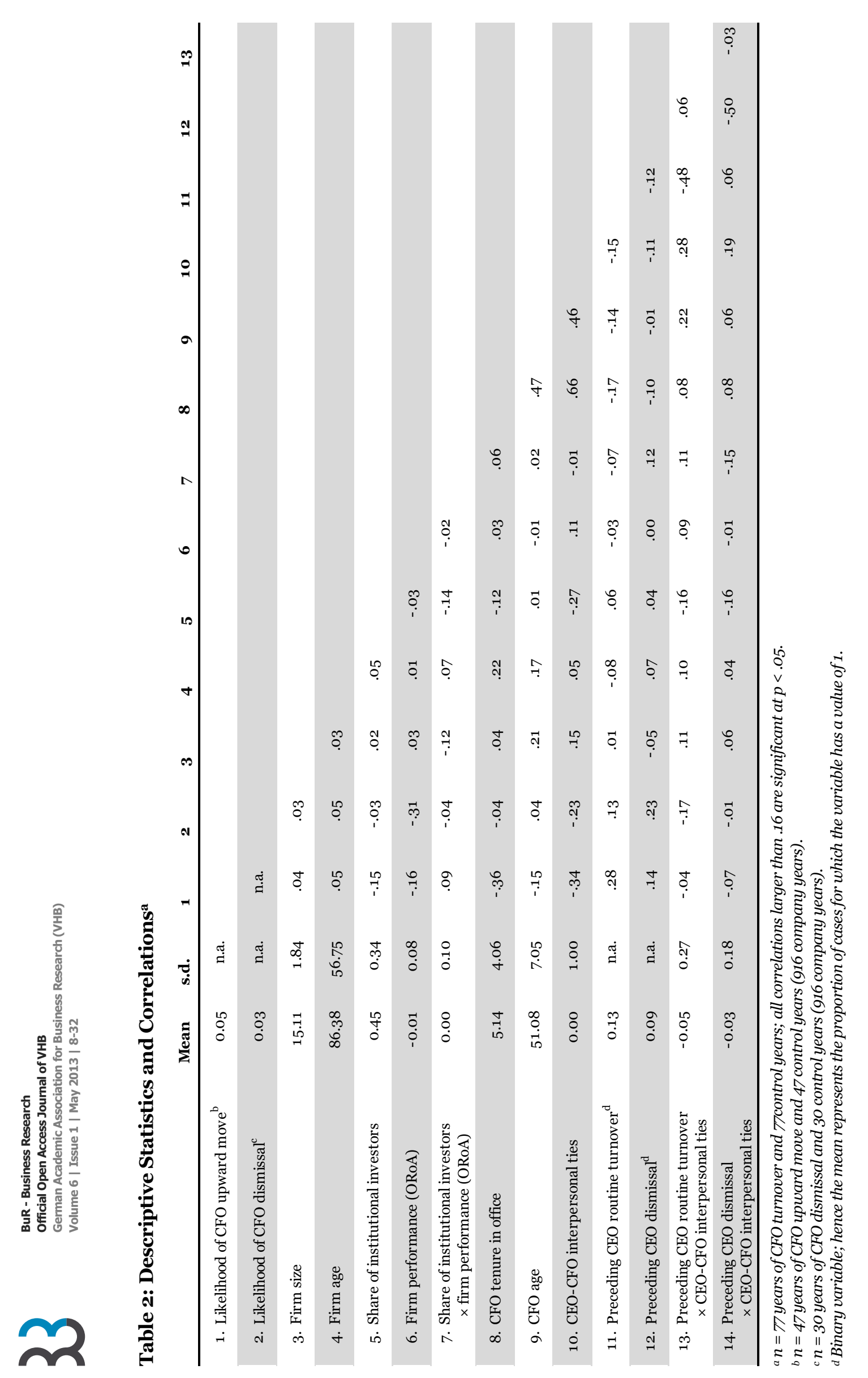


In order to test Hypothesis 1, we estimated three different regression models where we examined the likelihood of CFO upward move or dismissal (Table $3)$. The first model (1.1) is the controls only model. We found a significant $(p<0.01)$ negative impact of the control variables firm performance and $C F O$ tenure in office. Hence, in line with previous research, poor firm performance increases the likelihood of CFO turnover. Furthermore, CFOs leaving their position involuntarily or for upward moves do so after a short tenure in office. In addition, a small share of institutional investors appears to increase the likelihood of a CFO upward move or dismissal ( $p<0.05$ ), which stands in contrast to the findings by Denis and Serrano (1996) as well as Denis, Denis, and Sarin (1997).

Likelihood Ratio (LR) tests showed that inclusion of the variable $C E O-C F O$ interpersonal ties in model 1.2 led to an improvement in model quality (Pseudo $\left.R^{2}=0.15 ; \mathrm{LRX}^{2}=30.86, p<0.001\right)$. The coefficient on $C E O-C F O$ interpersonal ties is negative and significant $(p<0.05)$, implying that a strong relationship between a TMT member and the CEO decreases the likelihood of turnover, which supports Hypothesis 1. In a next step, we included the variables preceding CEO routine turnover and preceding CEO dismissal in model 1.3, which produced a further improvement in model quality (Pseudo $R^{2}=$ 0.21; $\left.\mathrm{LR}^{2}=43.62, p<0.001\right)$. The coefficients on preceding CEO routine turnover and preceding $C E O$ dismissal were positive and significant $(p<$ 0.01 respectively $p<0.05$ ).

In order to test Hypotheses $2 \mathrm{a}$ and $2 \mathrm{~b}$, we estimated logistic regression models 2.1-2.4 (Table 4), where we examined the relationship between $C E O$ routine turnover and subsequent $C F O$ upward move. In a first model (2.1), we introduced the control variables. As expected, the explanatory power of this model is limited. Just as before, we found a significant $(p<0.01)$ negative impact of the control variable CFO tenure in office. Hence, CFOs leaving their position for upward moves do so after a short tenure in office.

In a second step, we included the variable $C E O-C F O$ interpersonal ties in model 2.2, which led to a significant improvement in model quality (Pseudo $R^{2}=$ $\left.0.23 ; \mathrm{LR}^{2}=29.14, p<0.001\right)$. Including the variables preceding CEO routine turnover and preceding $C E O$ dismissal in model 2.3 led to a further improvement in model quality (Pseudo $R^{2}=0.30$;
$\left.\mathrm{LR} \chi^{2}=38.44, p<0.001\right)$. The coefficient on preceding $C E O$ dismissal was positive, but not significant, and the coefficient on preceding $C E O$ routine turnover was positive and significant $(p<0.01)$. This result supports Hypothesis 2a.

In the final model 2.4, we introduced the interaction term preceding $\mathrm{CEO}$ routine turnover $\times \mathrm{CEO}-\mathrm{CFO}$ interpersonal ties. Again, the overall model quality improved (Pseudo $R^{2}=0.31 ; \mathrm{LR}^{2}=39.32, p<$ o.001), providing confirmatory evidence that the interaction between interpersonal ties and CEO routine turnover supports explanations of $\mathrm{CFO}$ upward moves.

However, in logistic regressions the coefficients and their associated significance levels of multiplicative interaction terms are unreliable guides for the true interaction effects (Hoetker 2007). Therefore, we calculated the true interaction effect and its $z$ statistics, based on the estimated cross-partial derivative (Ai and Norton 2003). For another example of the application of this method see Lel and Miller (2008).

Figure 2 shows the results. We find that the true interaction effect has a mean of 0.22 and is positive throughout (i.e., there is not a single observation for which it is negative), although it varies widely. For CFOs whose predicted probability of upward move is between 0.3 and 0.7 , the interaction effect between preceding $C E O$ routine turnover and $C E O$ CFO interpersonal ties is highest, whereas it is low for CFOs with either a high ( $>0.8$ ) or a low $(<0.2)$ predicted probability of upward move. We only find statistically significant $(p<0.05)$ interaction effects for a few cases where CFOs have a predicted probability of making an upward move greater than 0.1 (Norton, Wang, and Ai 2004). This result provides tentative evidence supporting Hypothesis $2 b$. In order to check the robustness of our results, we also tested our hypotheses without the four cases of a promotion to the supervisory board. The results are comparable to the ones we report above, and we also detect comparable interaction effects.

In order to test Hypotheses $3 \mathrm{a}$ and $3 \mathrm{~b}$, we estimated regression models 3.1-3.4 (Table 5), where we examined the relationship between CEO dismissal and subsequent $C F O$ dismissal. As for the case of CFO upward move, we first introduced the control variables in model 3.1. The explanatory power is limited, as expected, and we only found a negative and significant $(p<0.05)$ impact of the variable 


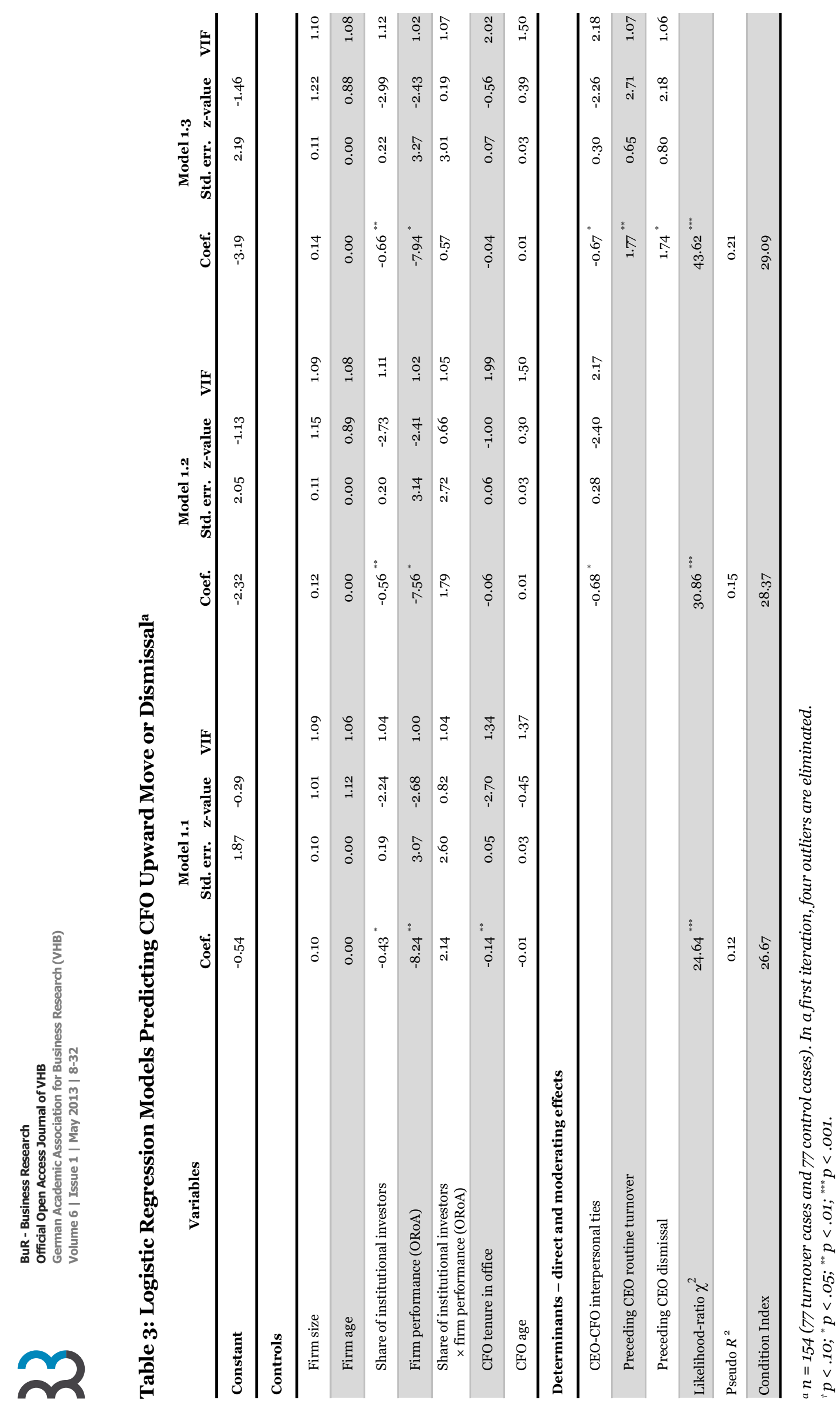




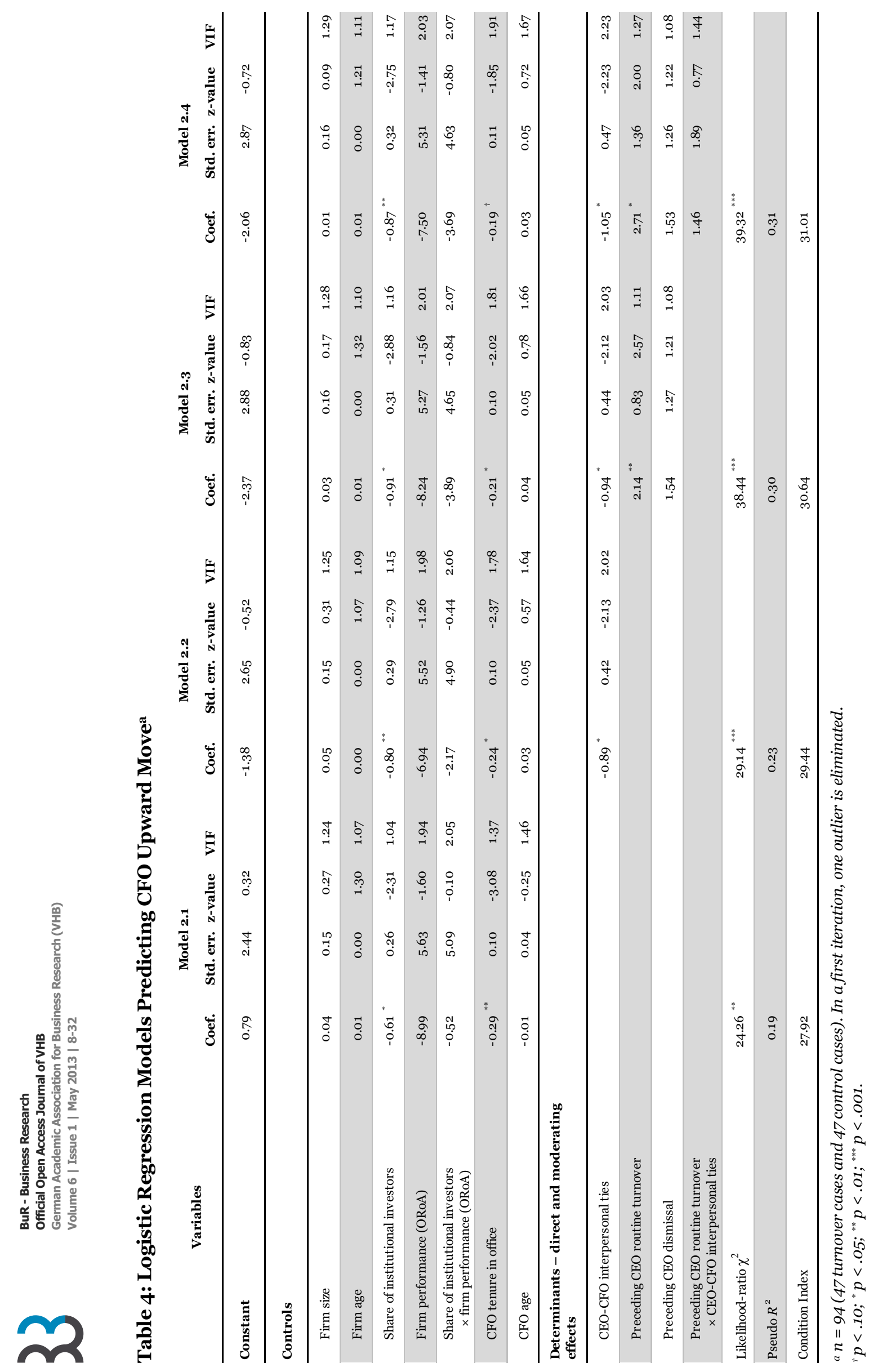




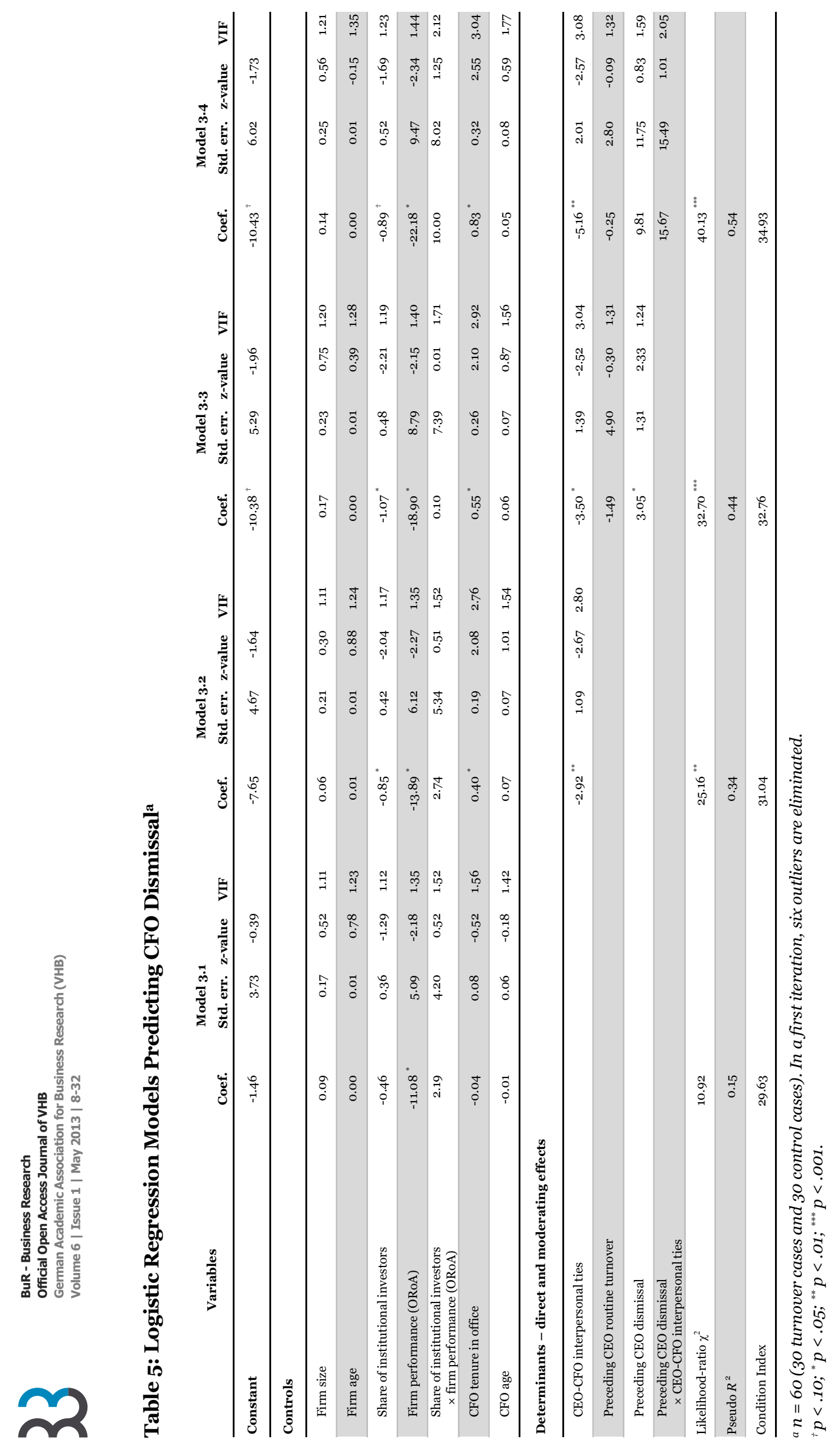


firm performance, implying that poor firm performance increases the likelihood that the $\mathrm{CFO}$ is fired (see also Mian 2001). In model 3.2, we included the variable $C E O-C F O$ interpersonal ties, which led to a significant improvement in model quality (Pseudo $\left.R^{2}=0.34 ; \mathrm{LRX}^{2}=25.16 ; p<0.01\right)$. Including the variables preceding $C E O$ routine turnover and preceding CEO dismissal in model 3.3 further improved the overall model quality (Pseudo $R^{2}=0.44$; $\left.\mathrm{LR} \chi^{2}=32.70 ; p<0.001\right)$. The coefficient on preceding $C E O$ dismissal was positive and significant $(p<$ 0.05), which supports Hypothesis 3a that a CEO dismissal increases the likelihood of CFO dismissal. This effect holds even if firm performance is good, a situation in which the CFO might have hopes of being promoted to the CEO position.

In the final model 3.4, we introduced the interaction term preceding $C E O$ dismissal $\times C E O-C F O$ interpersonal ties, in order to test Hypothesis $3 \mathrm{~b}$. Again, the model quality improved quite considerably as a result of including this moderating variable (Pseudo $\left.R^{2}=0.54 ; \mathrm{LR}^{2}=40.13, p<0.001\right)$. Therefore, our results also provide confirmatory evidence for $\mathrm{Hy}$ pothesis $3 \mathrm{~b}$.

Figure 3 illustrates the true interaction effect and its $z$-statistics. Similar to the case of $C F O$ upward move, we also find for $C F O$ dismissal that the true interaction effect is positive (mean $=0.92$ ) across the entire range of observations, and varies widely. It also depends on other covariates. For CFOs whose predicted probability of being dismissed is between 0.3 and 0.7 , the interaction effect between preceding $\mathrm{CEO}$ dismissal and $\mathrm{CEO}-\mathrm{CFO}$ interpersonal ties is highest, whereas it is low for CFOs with either a high $(>0.8)$ or low $(<0.2)$ predicted probability of being dismissed. Nevertheless, we only find statistically significant $(p<0.05)$ interaction effects for a few cases where CFOs have a predicted probability of being dismissed between 0.3 and 0.6 (Norton, Wang, and Ai 2004). This result supports Hypothesis $3 \mathrm{~b}$. However, it also shows that interpersonal ties do not necessarily moderate the relationship between CEO and CFO turnover.

A comparison of Figures 2 and 3 also suggests that the interaction effect of $\mathrm{CEO}$-CFO interpersonal ties is higher in case both executives are dismissed (Figure 3) than in case they leave on a routine basis (Figure 2), but we find a greater number of statistically significant incidences for the latter case.

\section{$5 \quad$ Discussion and Conclusion}

\subsection{Summary and Discussion}

In this paper, we have investigated the implications of interpersonal ties to the CEO for the career prospects of top managers. Drawing on the literature on the importance of social networks, in particular in TMTs (Cao, Maruping, and Takeuchi 2006; Collins and Clark 2003; Nahapiet and Ghoshal 1998; Rank and Tuschke 2010), we argued that under normal conditions, managers glean special protection and other benefits from a strong relationship with the CEO of their firm. Therefore, strong interpersonal ties increase the likelihood that individual TMT members stay in office. If the CEO vacates their position for routine reasons, we expect this departure to have positive career implications for the TMT member. A strong relationship with the departing CEO should further reinforce this effect. However, if the CEO is dismissed from office, a strong relationship between a top manager and that CEO should also increase the negative spillover effect of the CEO's dismissal on the career prospects of the manager concerned, e.g., by raising the risk that the manager is fired, too.

We investigate the career implications of interpersonal ties to the CEO from the perspective of a top manager whose specific role exists in the vast majority of large-scale companies - more often so than any other senior executive role -, namely the CFO. The fact that the CFO, as the "chief strategic partner" of the CEO (Arthaud-Day, Certo, Dalton, and Dalton 2006; Zorn 2004), has to balance the desirability of a close relationship with the CEO and the need to keep some professional distance from them for the sake of a more independent judgment (Daily and Schwenk 1996), is a further reason why the CFO position constitutes a particularly interesting context for our analysis.

To test our hypotheses, we used a sample of 77 CFO turnover events - cases in which the respective manager either made an upward move, or was dismissed - in large-scale, publicly quoted companies in Germany from 1999 to 2006. Employing a matched-pair design, we compare these cases with a corresponding set of 77 control company-year observations in which no turnover event took place. Our measure of interpersonal ties to the CEO is of a 
Figure 2: Interaction Effect in the Case of CFO Upward Move
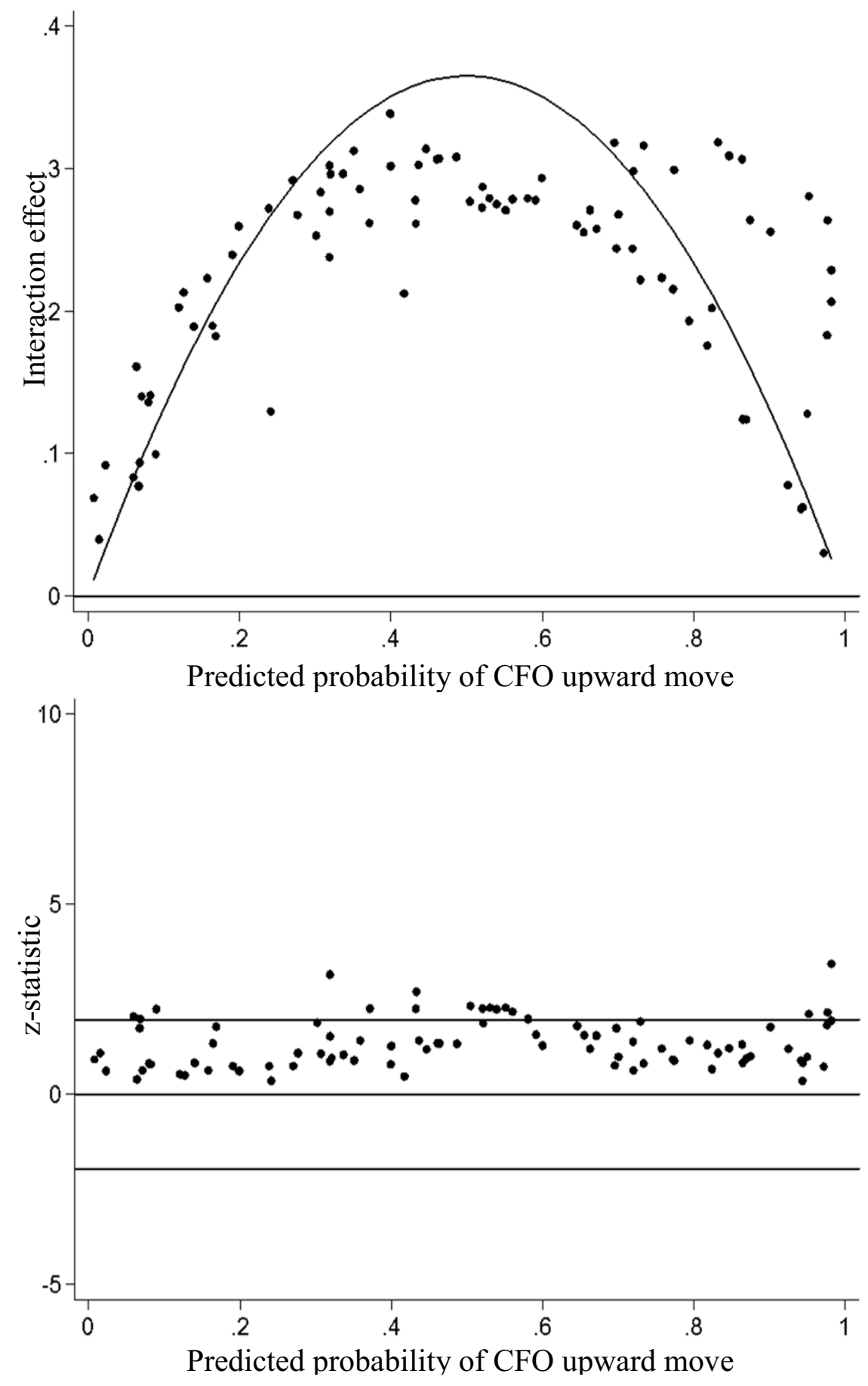

Note: The graphical illustration shows the magnitude of the interaction coefficient across the range of predicted probabilities of CFO upward move and corresponding z-values. Interaction coefficients with a z-value above and below the plotted threshold ( \pm 1.96$)$ are significant at $p<.05$. 
Figure 3: Interaction Effect in the Case of CFO Dismissal
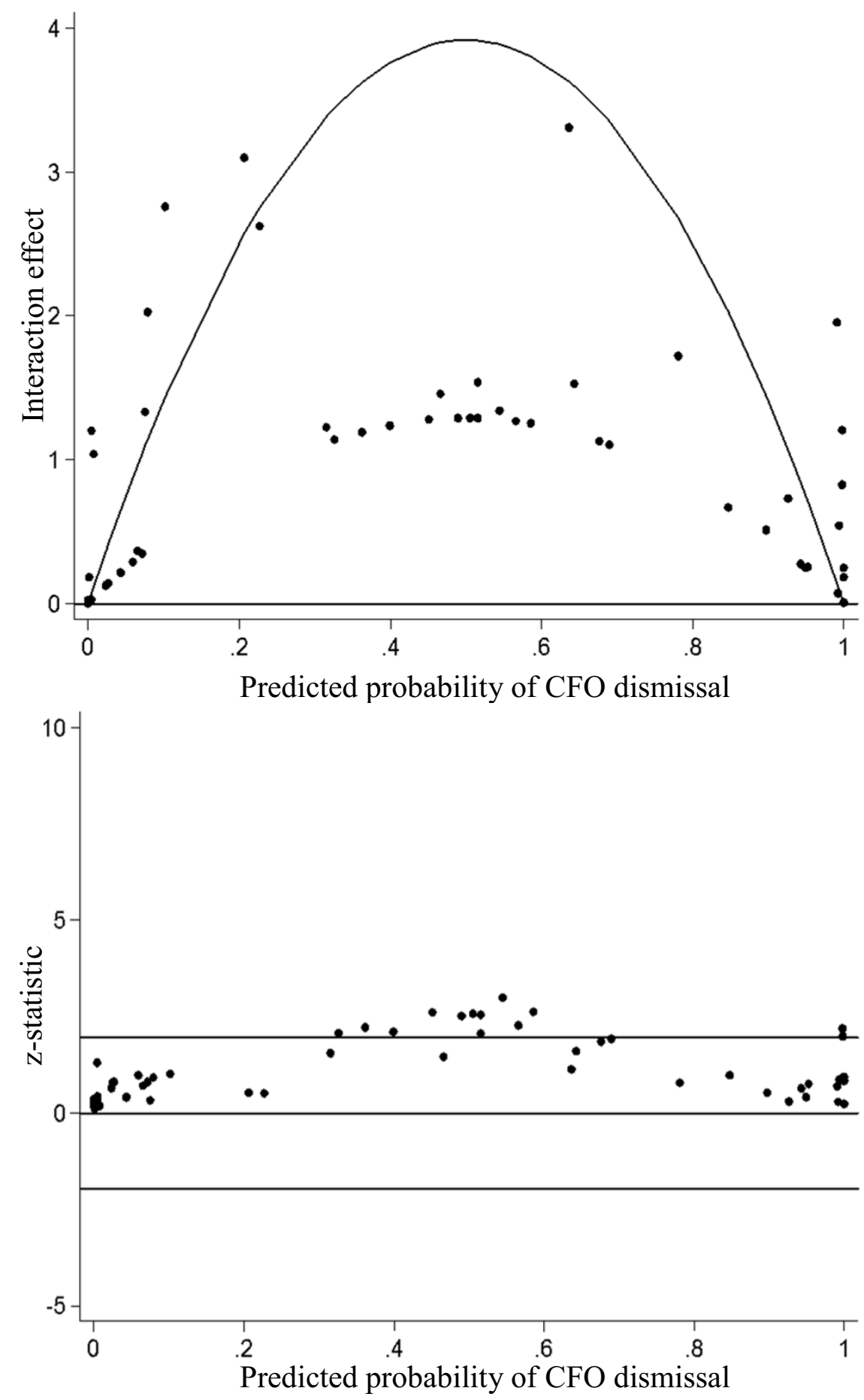

Note: The graphical illustration shows the magnitude of the interaction coefficient across the range of predicted probabilities of CFO dismissal and corresponding $\mathrm{z}$-values. Interaction coefficients with a z-value above and below the plotted threshold ( \pm 1.96$)$ are significant at $p<.05$. 
multidimensional nature, taking into account $\mathrm{mu}$ tual tenure in office, mutual firm tenure, age difference, simultaneous entrance in office, and common field of study. Factor analysis showed that these five proxies loaded on one factor.

Our regression analyses provide support for $\mathrm{Hy}-$ pothesis 1 that strong interpersonal ties to the CEO decrease the likelihood of turnover for the TMT member concerned (in our analysis, the CFO) significantly. Therefore, our analysis indicates that, under normal conditions, interpersonal ties to the CEO are a source of stability that helps keep a manager in their position. However, if a CEO leaves office for routine reasons, this event increases the likelihood that the manager concerned makes an upward career move, thus confirming Hypothesis $2 a$.

In order to examine whether strong interpersonal ties reinforce this effect, we employed the graphical analysis proposed by Ai and Norton (2003) and Norton, Wang, and Ai (2004) to illustrate the true interaction effect, as in logistic regression conventional multiplicative terms are an unreliable indicator for such interaction effects (Hoetker 2007). This analysis provides tentative evidence in support of our Hypothesis $2 b$ that strong interpersonal ties to the CEO increase the effect of the CEO's routine departure on the likelihood that the manager concerned makes an upward career move. However, if the CEO is dismissed from office, the career prospects of the manager concerned are impaired and the likelihood that they are also dismissed, increased (Hypothesis 3a). Again, our analysis of the true interaction effect provides tentative evidence in support of Hypothesis $3 \mathrm{~b}$ that a strong relationship with the CEO further reinforces this negative spillover effect. In order to establish whether a dismissal of a TMT member had a detrimental effect on the career prospects of that manager in the longer run, we analyzed whether the 30 dismissed CFOs in our sample obtained at least an equivalent position to the one from which they had been dismissed within one year after the dismissal event. This was the case for only two CFOs, whereas the career progressions of the remaining 28 were negatively affected on a long-term basis (see also Fee and Hadlock 2004; Huson, Malatesta, and Parrino 2004). Therefore, if a strong relationship with a dismissed CEO increases a manager's risk of being dismissed, too, the negative career implications for the manager concerned appear substantial.
Overall, our findings add to the literature on social relationships in TMTs (Adler and Kwon 2002; Cao, Maruping, and Takeuchi 2006; Menz 2012) by revealing, for the first time, the career implications of interpersonal ties between a manager and the CEO. According to our analysis, such ties reinforce the effects of continuity or change in the CEO position on whether the manager concerned stays in office, makes an upward move, or is fired. Likewise, weak interpersonal ties may reduce the effects of what happens to the CEO, on the manager concerned. For example, if the CEO is dismissed, a weak relationship with that CEO may lower the risk that the manager is implicated in the CEO's perceived failure, and that they share the CEO's fate of dismissal. Viewed in this light, a strong relationship with the CEO can be a liability as well as an advantage for a top manager. While they may constitute an important source of team-specific human capital (Adler 2001; Adler and Kwon 2002), they may also increase the chances of the manager's own dismissal when the CEO is fired, for whichever reason.

Our findings indicate that interpersonal ties between top managers matter for decisions of governance bodies as to whether or not to take disciplinary actions. The dismissal of the CEO appears to have detrimental consequences for the continuance in office of an incumbent manager, especially if he or she has held strong relationships with the dismissed CEO. The supervisory board or the new CEO successor themselves cannot assume that the manager, if they stay in office, will be able to build sufficient trust and working relationships with the new CEO, as they are seen as the dismissed CEO's "partner in crime" (Shen and Cannella 2002b; Virany, Tushman, and Romanelli 1992).

Moreover, we find that CEO routine turnover increases the likelihood that another member of the TMT is internally promoted or makes an advantageous career move externally. The fact that a CEO leaves the company voluntarily opens up opportunities within or outside the firm for a manager, meaning that they can be promoted to the CEO position, or that they may follow the leaving CEO to a new organization. Furthermore, if not promoted to the CEO position, it seems advantageous for the manager concerned to leave the organization voluntarily, especially if they worked together with the departed CEO for a longer period of time and was part of their social network (Cao, Maruping, and Takeuchi 2006). The new CEO may have an incentive to re- 
place the incumbent TMT member by someone they have already built a strong relationship with. The observed moderating effect of interpersonal ties is higher in cases where both executives are dismissed than in cases where they leave on a routine basis.

Our findings are broadly in line with agencytheoretic approaches to the cascading set of principal-agent relationships in organizations. Classical agency perspectives focus on the relationship between managers (as agents) and "distant" shareholders (as principals) (Berle and Means 1932; Eisenhardt 1989; Sappington 1991). From the perspective of the latter group, close ties among the members of the former provide opportunities for collusive behavior and make it harder to monitor managers on an individual basis (Daily and Schwenk 1996; Ocasio 1994). Therefore, such interpersonal ties create linkages between the career moves of the managers concerned, be they positive (as in the case of upward career moves), or negative (as in the case of joint dismissal).

In contrast to much of the literature on social networks in TMTs, our research emphasizes the individual-level (rather than the organization- or the team-level) effects of interpersonal ties between managers, specifically, the career implications of such ties. Clearly, there are many team-level benefits of interpersonal ties, too; for example, such ties are an important antecedent to the behavioral integration of TMT (Hambrick 1995, 2007), which, in turn, raises firm performance (Lubatkin, Simsek, Ling, and Veiga 2006). However, a well-integrated team is also more likely to be held collectively accountable for its actions, in particular in a corporate governance context such as Germany's which places significant emphasis on the principle of collective responsibility ( $\$ 77$ Section 1 AktG).

From the perspective of an individual manager, interpersonal ties create spillover effects that may be positive as well as negative: They can help advance one's career, but they can also be detrimental to it. Furthermore, although interpersonal ties involve primarily the two parties involved in a relationship, our findings suggest that third parties - such as supervisory boards - may play a role in them, too, namely through their perception of that tie. Simply speaking, a manager who has a strong relationship with an even more powerful figure such as the CEO is seen differently than one with just a weak relationship. In social psychology, the phenomenon that people tend to make inferences about a person on the basis of their relationships with others is well established (Casciaro 1998; Gage and Cronbach 1955). In this study, we provide indications that similar mechanisms may be at work in a management context, too.

Our study has several limitations that need discussing. First, as is the case in other studies (e.g., Fee and Hadlock 2004; Mian 2001), the size of our sample was moderate. However, it has to be taken into consideration that the population into which our study generalizes - large, publicly quoted companies in a homogeneous governance context (in this case, Germany) - is also fairly limited. Further work should aim at testing the importance of interpersonal ties between top managers across different governance contexts.

Second, classifying turnover events and distinguishing between different turnover types turned out to be a complex task. We sought to address this challenge by gathering extensive information on executive turnover which was evaluated by two raters working independently. We did not consider it appropriate to include smaller companies or to extend the period of analysis in order to include additional turnover events before 1999 because doing so would have led to distortions in the comparability of the companies within the sample.

Third, in line with other studies (e.g., Cao, Maruping, and Takeuchi 2006; Granovetter 1973), we used a composite indicator to measure the strength of the interpersonal ties between the CEO and the CFO. We tried to account for the multidimensionality of interpersonal ties by calculating five different proxy measures and factor analyzing them. Our results did not change materially when we left aside three variables that can be interpreted as measures of homophily (age difference, simultaneous entrance in office, and common field of study) in order to concentrate exclusively on factors that are clearly unrelated to homophily, namely mutual tenure in office and mutual firm tenure. From our point of view, future work should seek to find even richer, potentially qualitative, measures of interpersonal ties than we were able to employ here. In particular, it would be important to include a measure of interaction frequency / intensity in such a measure of interpersonal ties, which we were able to approximate only, but not to measure directly. Further work on developing rich, multifaceted measures of interpersonal ties is urgently needed. 


\subsection{Implications for Managerial Practice}

Our study underlines the importance of TMT interpersonal ties in contemporary corporate management. The findings add to the results of previous studies confirming that top executives do not work in isolation (Hayes, Oyer, and Schaefer 2006). Although interpersonal ties relate primarily to the two parties involved in a relationship, our findings suggest that third parties - such as supervisory boards (or boards of directors, in the Anglo-Saxon context) - may play a role in them, too. Top executives with strong interpersonal ties to a CEO leaving for routine reasons may be perceived as a potential successor to that CEO. In contrast, top executives with strong interpersonal ties to a dismissed CEO may be perceived as their "partners in crime", which increases their likelihood of dismissal, too. Towards that end, it seems important for supervisory boards to take the team relationship with the CEO into account, but not to misjudge individual TMT members' performance by focusing solely on their interpersonal ties to the CEO.

From the perspective of individual managers, our research has shown how important the personal support of the CEO is. Strong interpersonal ties to the CEO are a source of stability, thus raising the likelihood that a manager stays in office. In situations where the CEO leaves office for routine reasons, strong ties with the CEO enhance the possibilities for the manager to make an upward move. However, the dismissal of the CEO can jeopardize a manager's professional advancement, including their chances of taking over the CEO position. In such a case, or if personal differences with an existing or newly appointed CEO surface or are in the offing, voluntary departure to a position outside the company appears an alternative worth considering for a manager's further professional development.

\section{Acknowledgements}

We would like to thank Volker Büttner and Kevin Zander for their support. We are also very grateful to Klaus Uhlenbruck for his valuable feedback on earlier versions of this paper. Finally, we benefited considerably from the helpful comments received by two anonymous reviewers and the department editor, Peter Walgenbach.

\section{References}

Adler, Paul S. (2001): Market, Hierarchy, and Trust: The Knowledge Economy and the Future of Capitalism, Organization Science, 12 (2): 215-234.

Adler, Paul S. and Seok-Woo Kwon (2002): Social Capital: Prospects for a New Concept, Academy of Management Review, 27 (1): 17-40.

Ai, Chunrong and Edward C. Norton (2003): Interaction Terms in Logit and Probit Models, Economic Letters, 80 (1): 123-129.

Arthaud-Day, Marne L., S. Trevis Certo, Catherine M. Dalton, and Dan R. Dalton (2006): A Changing of the Guard: Executive and Director Turnover Following Corporate Financial Restatements, Academy of Management Journal, 49 (6): 1119-1136.

Barnett, William P. and Glenn R. Carroll (1995): Modeling Internal Organizational Change, Annual Review of Sociology, 21: 217237.

Baums, Theodor and Kenneth E. Scott (2005): Taking Shareholder Protection Seriously? Corporate Governance in the U.S. and Germany, Journal of Applied Corporate Finance, 17 (4): 44-63.

Baxter, Jane and Wai Fong Chua (2008): Be(com)ing the Chief Financial Officer of an Organisation: Experimenting With Bourdieu's Practice Theory, Management Accounting Research, 19 (3): 212-230.

Berle, Adolf A. and Gardiner C. Means (1932): The Modern Corporation and Private Property, Macmillan: New York, NY.

Boeker, Warren (1997): Strategic Change: The Influence of Managerial Characteristics and Organizational Growth, Academy of Management Journal, 40 (1): 152-170.

Boeker, Warren and Jerry Goodstein (1993): Performance and Successor Choice: The Moderating Effects of Governance and Ownership, Academy of Management Journal, 36 (1): 172-186.

Bresser, Rudi K. F. and Reynaldo Valle Thiele (2008): Ehemalige Vorstandsvorsitzende als Aufsichtsratschefs: Evidenz zu ihrer Effektivität im Falle des erzwungenen Führungswechsels, Zeitschrift für Betriebswirtschaft, 78 (2): 175-203.

Bresser, Rudi K. F., Reynaldo Valle Thiele, Annette Biedermann, and Holger Lüdeke (2005): Entlassung des Vorstandsvorsitzenden und Unternehmenserfolg: Eine empirische Untersuchung der größten deutschen Aktiengesellschaften, Zeitschrift für Betriebswirtschaft, 75 (12): 1165-1192.

Burt, Ronald S. (1997): The Contingent Value of Social Capital, Administrative Science Quarterly, 42 (2): 339-365.

Cannella, Albert A. Jr. and Michael Lubatkin (1993): Succession as a Sociopolitical Process: Internal Impediments to Outsider Selection, Academy of Management Journal, 36 (4): 763-793.

Cao, Qing, Likoebe M. Maruping, and Riki Takeuchi (2006): Disentangling the Effects of CEO Turnover and Succession on Organizational Capabilities: A Social Network Perspective, Organization Science, 17 (5): 563-576.

Carpenter, Mason A., Marta A. Geletkanycz, and William Gerard Sanders (2004): Upper Echelons Research Revisited: Antecedents, Elements, and Consequences of Top Management Team Composition, Journal of Management, 30 (6): 749-778.

Casciaro, Tiziana (1998): Seeing Things Clearly: Social Structure, Personality, and Accuracy in Social Network Perception, Social Networks, 20 (4): 331-351. 
Cohen, Jacob (1960): A Coefficient of Agreement for Nominal Scales, Educational and Psychological Measurement, 20 (1): 3746.

Coleman, James S. (1988): Social Capital in the Creation of Human Capital, American Journal of Sociology, 94 (Supplement): 95-120.

Collins, Christopher J. and Kevin D. Clark (2003): Strategic Human Resource Practices, Top Management Team Social Networks, and Firm Performance: The Role of Human Resource Practices in Creating Organizational Competitive Advantage, Academy of Management Journal, 46 (6): 740-751.

Collins, Denton, Adi Masli, Austin L. Reitenga, and Juan Manuel Sanchez (2009): Earnings Restatements, the Sarbanes-Oxley Act, and the Disciplining of Chief Financial Officers, Journal of Accounting, Auditing, and Finance, 24 (1): 1-34.

Coughlan, Anne T. and Ronald M. Schmidt (1985): Executive Compensation, Management Turnover, and Firm Performance: An Empirical Investigation, Journal of Accounting and Economics, $7(1-3)$ : 43-66.

Cruz, Cristina C., Luis R. Gomez-Mejia, and Manuel Becerra (2010): Perceptions of Benevolence and the Design of Agency Contracts: CEO-TMT Relationships in Family Firms, Academy of Management Journal, 53 (1): 69-89.

Daily, Catherine M. and Charles Schwenk (1996): Chief Executive Officers, Top Management Teams, and Boards of Directors: Congruent or Countervailing Forces? Journal of Management, 22 (2): $185-208$.

Datta, Deepak K., and Guthrie, James P. (1994): Executive Succession: Organizational Antecedents of CEO Characteristics, Strategic Management Journal, 15 (7): 569-577.

Denis, David J. and Diane K. Denis (1995): Performance Changes Following Top Management Dismissals, Journal of Finance, 50 (4): 1029-1057.

Denis, David J. and Jan M. Serrano (1996): Active Investors and Management Turnover Following Unsuccessful Control Contests, Journal of Financial Economics, 40 (2): 239-266.

Denis, David J., Diane K. Denis, and Atulya Sarin (1997): Ownership Structure and Top Executive Turnover, Journal of Financial Economics, 45 (2): 193-221.

Dowdell, Thomas D. and Jagan Krishnan (2004): Former Audit Firm Personnel as CFOs: Effect on Earnings Management, Canadian Accounting Perspectives, 3 (1): 117-142.

Eisenhardt, Kathleen M. (1989): Agency Theory: An Assessment and Review, Academy of Management Review, 14 (1): 57-74

Fama, Eugene F. (1980): Agency Problems and the Theory of the Firm, Journal of Political Economy, 88 (2): 288-307.

Fee, C. Edward and Charles J. Hadlock (2004): Management Turnover across the Corporate Hierarchy, Journal of Accounting and Economics, 37 (1): 3-38.

Financial Reporting Council (2010): The UK Corporate Governance Code, https://www.frc.org.uk/getattachment/bo832de25c94-48co-b771-ebb249fe1fec/The-UK-Corporate-GovernanceCode.aspx (Access date: 2013-03-13).

Finkelstein, Sydney and Donald C. Hambrick (1990): TopManagement-Team Tenure and Organizational Outcomes: The Moderating Role of Managerial Discretion, Administrative
Science Quarterly, 35 (3): 484-503.

Finkelstein, Sydney, Donald C. Hambrick, and Albert A. Cannella Jr. (2009): Strategic Leadership: Theory and Research on Executives, Top Management Teams, and Boards, Oxford University Press: Oxford, UK et al.

Friedman, Stewart D. and Harbir Singh (1989): CEO Succession and Stockholder Reaction: The Influence of Organizational Context and Event Content, Academy of Management Journal, 32 (4): 718-744.

Gage, Nathaniel L. and Lee J. Cronbach (1955): Conceptual and Methodological Problems in Interpersonal Perception, Psychological Review, 62 (6): 411-422.

Geiger, Marshall A. and David S. North (2006): Does Hiring a New CFO Change Things? An Investigation of Changes in Discretionary Accruals, Accounting Review, 81 (4): 781-809.

Geiger, Marshall A., David S. North, and Brendan T. O'Connell (2005): The Auditor-to-Client Revolving Door and Earnings Management, Journal of Accounting, Auditing and Finance, 20 (1): 1-26.

Geletkanycz, Marta A. and Donald C. Hambrick (1997): The External Ties of Top Executives: Implications for Strategic Choice and Performance, Administrative Science Quarterly, 42 (4): 654681.

Graffin, Scott D., James B. Wade, Joseph F. Porac, and Robert C. McNamee (2008): The Impact of CEO Status Diffusion on the Economic Outcomes of Other Senior Managers, Organization Science, 19 (3): 457-474.

Granovetter, Mark S. (1973): The Strength of Weak Ties, American Journal of Sociology, 78 (6): 1360-1380.

Hambrick, Donald C. (1995): Fragmentation and the Other Problems CEOs Have With Their Top Management Teams, California Management Review, 37 (3): 110-127.

Hambrick, Donald C. (2007): Upper Echelons Theory: An Update, Academy of Management Review, 32 (2): 334-343.

Hambrick, Donald C. and Phyllis A. Mason (1984): Upper Echelons: The Organization as a Reflection of Its Top Managers, Academy of Management Review, 9 (2): 193-206.

Hambrick, Donald C., Marta A. Geletkanycz, and James W. Fredrickson (1993): Top Executive Commitment to the Status Quo: Some Tests of Its Determinants, Strategic Management Journal, 14 (6): 401-418.

Hayes, Rachel M., Paul Oyer, and Scott Schaefer (2006): Coworker Complementarity and the Stability of Top-Management Teams, Journal of Law, Economics and Organization, 22 (1): 184-212.

Hermalin, Benjamin E. and Michael S. Weisbach (1998): Endogenously Chosen Boards of Directors and Their Monitoring of the CEO, American Economic Review, 88 (1): 96-118.

Hoetker, Glenn (2007): The Use of Logit and Probit Models in Strategic Management Research: Critical Issues, Strategic Management Journal, 28 (4): 331-343

Huson, Mark R., Paul H. Malatesta, and Robert Parrino (2004): Managerial Succession and Firm Performance, Journal of Financial Economics, 74 (2): 237-275.

Huson, Mark R., Robert Parrino, and Laura T. Starks (2001): Internal Monitoring Mechanisms and CEO Turnover: A LongTerm Perspective, Journal of Finance, 56 (6): 2265-2297. 
Jensen, Michael C. and William H. Meckling (1976): Theory of the Firm: Managerial Behavior, Agency Costs and Ownership Structure, Journal of Financial Economics, 3 (4): 305-360.

Kaplan, Steven N. (1994): Top Executives, Turnover, and Firm Performance in Germany, Journal of Law, Economics and Organization, 10 (1): 142-159.

Keck, Sara L. (1997): Top Management Team Structure: Differential Effects by Environmental Context, Organization Science, 8 (2): 143-156.

Kesner, Idalene F. and Dan R. Dalton (1994): Top Management Turnover and CEO Succession: An Investigation of the Effects of Turnover on Performance, Journal of Management Studies, 31 (5): 701-713.

Khanna, Naveen and Annette B. Poulsen (1995): Managers of Financially Distressed Firms: Villains or Scapegoats?, Journal of Finance, 50 (3): 919-940.

Kleinbaum, Adam M., Toby E. Stuart, and Michael L. Tushman (2011): Discretion With the Constraints of Opportunity: Gender Homophily and Structure in a Formal Organization, Working Paper, http://www.hbs.edu/faculty/Publication\%20Files/12050.pdf (Access date: 2013-03-15).

Lambert, Richard A., David F. Larcker, and Keith Weigelt (1993): The Structure of Organizational Incentives, Administrative Science Quarterly, 38 (3): 438-461.

Leana, Carrie R. and Harry J. Van Buren III (1999): Organizational Social Capital and Employment Practices, Academy of Management Review, 24 (3): 538-555.

Ledford, Gerald E. Jr. (1999): Happiness and Productivity Revisited, Journal of Organizational Behavior, 20 (1): 25-30.

Lel, Ugur and Darius P. Miller (2008): International CrossListing, Firm Performance, and Top Management Turnover: A Test of the Bonding Hypothesis, Journal of Finance, 63 (4): 18971937.

Lin, Nan (2001): Social Capital: A Theory of Social Structure and Action, Cambridge University Press: Cambridge, UK et al.

Logue, Danielle (2010): Top Management Team Composition: Asking Institutional Questions About Who Is "In", When and Why?, European Management Review, 7 (1): 71-72.

Lubatkin, Michael H., Zeki Simsek, Yan Ling. and John F. Veiga (2006): Ambidexterity and Performance of Small- to MediumSized Firms: The Pivotal Role of Top Management Team Behavioral Integration, Journal of Management, 32 (5): 646-672.

Lucier, Chuck, Rob Schuyt and Edward Tse (2005): CEO Succession 2004: The World's Most Prominent Temp Workers, Strategy and Business, 39: 1-16.

Menon, Krishnagopal and David D. Williams (2008): Management Turnover Following Auditor Resignations, Contemporary Accounting Research, 25 (2): 567-604.

Menz, Markus (2012): Functional Top Management Team Members: A Review, Synthesis, and Research Agenda, Journal of Management, 38 (1): 45-80.

Mian, Shehzad (2001): On the Choice and Replacement of Chief Financial Officers, Journal of Financial Economics, 60 (1): 143175 .

Mooney, Ann C. and Allen C. Amason (2011): In Search of the CEO's Inner Circle and How It Is Formed, in: Mason A. Carpenter (ed.): The Handbook of Research on Top Management Teams, Edward Elgar: Cheltenham, UK et al., 35-48.

Nahapiet, Janine and Sumantra Ghoshal (1998): Social Capital, Intellectual Capital, and the Organizational Advantage, Academy of Management Review, 23 (2): 242-266.

Nath, Pravin and Vijay Mahajan (2008): Chief Marketing Officers: A Study of Their Presence in Firms' Top Management Teams, Journal of Marketing, 72 (1): 65-81.

Nicholson, Nigel and David Cannon (2000): Two Views From the Bridge: How CFOs and SME Leaders Perceive Top Team Dynamics, European Management Journal, 18 (4): 367-376.

Norton, Edward C., Hua Wang, and Chunrong Ai (2004): Computing Interaction Effects and Standard Errors in Logit and Probit Models, The Stata Journal, 4 (2): 154-167.

O'Brien, Robert M. (2007): A Caution Regarding Rules of Thumb for Variance Inflation Factors, Quality \& Quantity, 41 (5): 673690.

Ocasio, William (1994): Political Dynamics and the Circulation of Power: CEO Succession in U.S. Industrial Corporations, 19601990, Administrative Science Quarterly, 39 (2): 285-312.

Ocasio, William and Hyosun Kim (1999): The Circulation of Corporate Control: Selection of Functional Backgrounds of New CEOs in Large U.S. Manufacturing Firms, 1981-1992, Administrative Science Quarterly, 44 (3): 532-562.

Perreault, William D. and Laurence E. Leigh (1989): Reliability of Nominal Data Based on Qualitative Judgments, Journal of Marketing Research, 26 (2): 135-148.

Rank, Olaf N. and Anja Tuschke (2010): Perceived Influence and Friendship as Antecedents of Cooperation in Top Management Teams: A Network Approach, Business Research, 3 (2): 151-171.

Rehbein, Kathleen (2010): Sarbanes-Oxley: Does It Help to Distinguish Good CFOs From Bad Ones?, Academy of Management Perspectives, 24 (4): 90-92.

Rodan, Simon and Charles Galunic (2004): More Than Network Structure: How Knowledge Heterogeneity Influences Managerial Performance and Innovativeness, Strategic Management Journal, 25 (6): 541-562.

Sappington, David E. M. (1991): Incentives in Principal-Agent Relationships, Journal of Economic Perspectives, 5 (2): 45-66.

Shen, Wei and Albert A. Cannella Jr. (2002a): Power Dynamics Within Top Management and Their Impacts on CEO Dismissal Followed by Inside Succession, Academy of Management Journal, 45 (6): 1195-1206.

Shen, Wei and Albert A. Cannella Jr. (2002b): Revisiting the Performance Consequences of CEO Succession: The Impacts of Successor Type, Postsuccession Senior Executive Turnover, and Departing CEO Tenure, Academy of Management Journal, 45 (4): 717-733.

Simsek, Zeki, John F. Veiga, Michael H. Lubatkin and Richard N. Dino (2005): Modeling the Multilevel Determinants of Top Management Team Behavioral Integration, Academy of Management Journal, 48 (1): 69-84.

Smith, Ken G., Christopher J. Collins, and Kevin D. Clark (2005) Existing Knowledge, Knowledge Creation Capability, and the Rate of New Product Introduction in High-Technology Firms, Academy of Management Journal, 48 (2): 346-357. 
Tulimieri, Philip and Moshe Banai (2010): A New Corporate Paradigm: The CEO and CFO - A Partnership of Equals, Organizational Dynamics, 39 (3): 240-247.

U.S. House of Representatives (2002): Sarbanes-Oxley Act of 2002 (H.R. 3763), U.S. House of Representatives: Washington, DC.

Virany, Beverly, Michael L. Tushman, and Elaine Romanelli (1992): Executive Succession and Organization Outcomes in Turbulent Environments: An Organization Learning Approach, Organization Science, 3 (1): 72-91.

Weisbach, Michael S. (1988): Outside Directors and CEO Turnover, Journal of Financial Economics, 20: 431-460.

Westphal, James D. and James W. Fredrickson (2001): Who Directs Strategic Change? Director Experience, the Selection of New CEOs, and Change in Corporate Strategy, Strategic Management Journal, 22 (12): 1113-1137.

Wiersema, Margarethe F. and Karen A. Bantel (1992): Top Management Team Demography and Corporate Strategic Change, Academy of Management Journal, 35 (1): 91-121.

Wiersema, Margarethe F. and Harry P. Bowen (2009): The Use of Limited Dependent Variable Techniques in Strategy Research: Issues and Methods, Strategic Management Journal, 30 (6): 679692.
Wrage, Markus, Anja Tuschke and Rudi Bresser (2011): Gut vernetzt. Warum Vorstandsvorsitzende häufig zu spät entlassen werden, Zeitschrift Führung + Organisation, 80 (5): 329-334.

Zorn, Dirk M. (2004): Here a Chief, There a Chief: The Rise of the CFO in the American Firm, American Sociological Review, 69 (3): $345-364$

\section{Biographies}

Stefan Hilger is a Research Fellow at the Department of Strategy, Organization \& Leadership at EBS Business School. He received his doctoral degree in Business Administration in 2012 from EBS Business School. In his research, he examines the use and effectiveness of different corporate governance mechanisms, with a particular focus on top executive turnover.

Ansgar Richter holds a PhD in Management from the London School of Economics and is Professor of Strategy and Organization at EBS Business School. His research interests revolve largely around the strategy, organization and governance of professional service firms, including consulting and law firms.

Utz Schäffer is Professor and Director of the Institute of Management Accounting and Control (IMC) at WHU - Otto Beisheim School of Management. His research is focused on the impact of the top management team on the design, use and implementation of management control systems. 